\title{
Primordial and Artificial Radioactivity Levels in Soil Samples of Hatay Region, Turkey
}

\author{
Muttalip Ergun Turgay \\ Electronic and Automation Division, Mustafa Kemal University, Hatay 31001, Turkey
}

\begin{abstract}
In this study, the radioactivity analysis was performed for soil samples of Hatay province which is in the Southeast region of Turkey. By gamma-ray spectrometry method, the average Radium (Uranium), Thallium (Thorium), Potassium and Cesium activity concentrations of totally 55 soil samples were measured as $23.35 \pm 1.40 \mathrm{Bqkg}^{-1}, 14.55 \pm 0.97 \mathrm{Bqkg}^{-1}, 242.36 \pm 20.12 \mathrm{Bqkg}^{-1}$ and $8.20 \pm 0.68 \mathrm{Bqkg}^{-1}$ respectively. There are a few values for the Uranium little bit up to the limit value of $33 \mathrm{Bqkg}^{-1}$. All values for the Thorium were lower than the limit value of $45 \mathrm{Bqkg}^{-1}$. Only a few values for the Potassium were little bit up to the limit value of $420 \mathrm{Bqkg}^{-1}$. Nearby the average for Hatay province is still under the limit value which were recommended by United Nations Scientific Committee on the Effects of Atomic Radiation (UNSCEAR). By using these activities, ADRA and AEDE values were calculated to get the outdoor Terrestrial Gamma Dose.
\end{abstract}

Key words: Radionuclides, activity, ADRA, AEDE, soil, Hatay.

\section{Introduction}

The largest contribution to total radiation dose received by humans, comes from Natural Radiation. Therefore environmental radioactivity measurements are necessary for determining the background radiation level. The natural radiation consists of cosmic rays and terrestrial radiation. Terrestrial component is due to radioactive nuclides that are present in the water, soil, air and building materials. The United Nations Scientific Committee on the Effects of Atomic Radiation (UNSCEAR) estimates the global average human exposure from natural radiation sources as $2.4 \mathrm{mSv}$ per year and radionuclides that are present of soil samples are considered to be responsible for a portion of this amount [1]. Over the past two decades, some results of radioactivity levels have been published in some papers for soil samples in Turkey ([3-10]). Nearby, there is no detailed study for Hatay region. Therefore, the purpose of this study is to determine the active

Corresponding author: Muttalip Ergun Turgay, Dr., assistant professor, research field: biomedical device technology program. concentrations of $\mathrm{U}, \mathrm{Th}, \mathrm{K}$ and $\mathrm{Cs}$ in soil samples collected from different locations throughout Hatay, and then assess the risk to human life by calculation of the terrestrial gamma dose.

\subsection{Sampling Area}

Hatay, the southeast province of Turkey, is near to board of Syria. It is located between $35^{\circ} 52^{\prime}-37^{\circ} 04^{\prime} \mathrm{N}$ as latitudes and $35^{\circ} 40^{\prime}-36^{\circ} 35^{\prime} \mathrm{E}$ as longitudes. Highest pick is Migirtepe $(2,240 \mathrm{~m})$. The territory of Hatay is covered by $46 \%$ mountain, $33 \%$ plain, $20 \%$ plateau and hillside. The Orontes River rises in the Bekaa Valley in Lebanon and runs through Syria and Hatay. There are some mineral deposits: Iskenderun is home to Turkey's largest iron and steel plant, and the district of Yayladagi produces a colorful marble called Rose of Hatay. Average temperature is $24.08{ }^{\circ} \mathrm{C}$ and average rainfall is $65 \mathrm{~mm}$. The region spans an area of $5,403 \mathrm{~km}^{2}$ and with a population of about 1.5 million [10]. The map of Hatay is shown in Fig. 1.

\subsection{Sample Collection and Settlements}

Sampling points were selected as uncultivated locations, close to dense population areas. Usually flat 


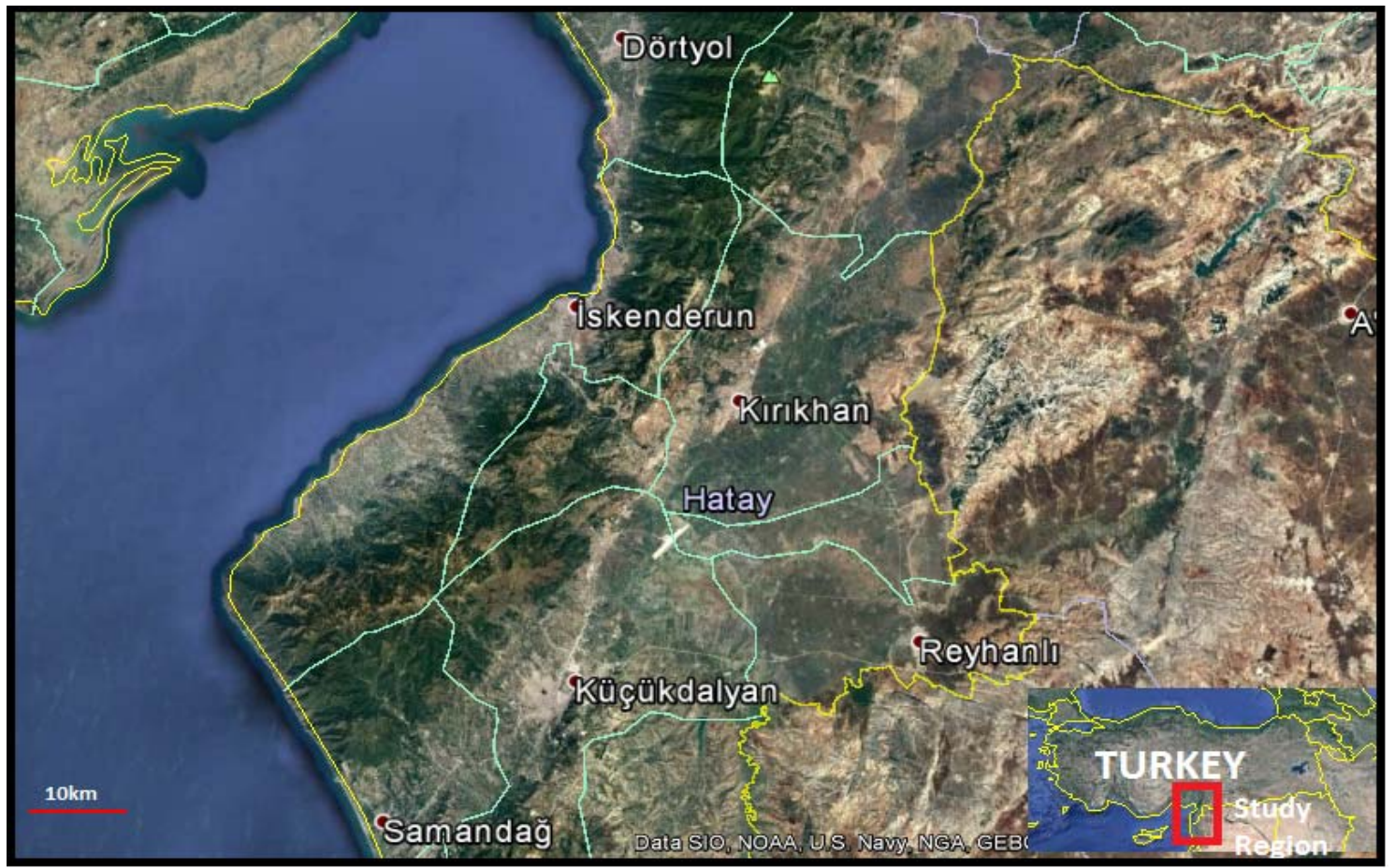

Fig. 1 Regional map of Hatay Province, Turkey [2].

and open areas was obtained and first, top soil of $5 \mathrm{~cm}$ from surface, was picked up. Samples were cleaned out the plants, stones etc., then sealed and numbered. After drying process ( 2 days) in the oven up to $100{ }^{\circ} \mathrm{C}$, all ones were elected through $2 \mathrm{~mm}$ sieve to get the homogenius sand form. Samples were filled to Marinelli containers regarding the nominal measurement geometry. Samples were kept during one month in order to assess the secular equilibrium between radium and decay products. System calibration was made by using of standard mixtures, gamma emitting radioisotopes in the same containers, in order to keep the geometry and measurement coincidence. Standards and samples were counted for the same time period, $50,000 \mathrm{~s}$, using the gamma transmission spectrum. In spectrum, it was used the ${ }^{226} \mathrm{Ra}(186.0 \mathrm{keV})$ peak in order to determine activity of Uranium. It was also used the ${ }^{208} \mathrm{Tl}(583.1 \mathrm{keV})$ peak in order to determine activity of Thorium.

\subsection{Measurement System}

Germanium detectors consist of active components as diodes. Ionizing radiation, high energetic $\mathrm{x}$-rays and also gamma can be measured by having a p-i-n structure in which the intrinsic (I) region. Intrinsic layer is undoped and pin diode is proper for its photodetector application. When a photon interacts with the material within the depleted volume of a detector, charge carriers; holes and electrons are produced and are also swept by the electric field to the $\mathrm{P}$ and $\mathrm{N}$ electrodes (Canberra, product brochure). This charge has direct corelation to the energy which deposited in the detector by the incident photon, is converted into a voltage pulse by an integral charge sensitive preamplifier. There are a few specifications were mentioned for the detector GX5020 [12] like that: Relative Efficiency is 50\%; Resolution is $2.0 \mathrm{keV}$ at $1.33 \mathrm{MeV}$ of FWHM from Co-60. Gamma Spectroscopy Software is Genie-2000, Multichannel Analyzer is DSA 100.

\section{Results}

Average activity concentrations for Uranium, Thorium, Potasium and Cesium are calculated to $23.35,14.55,242.36$ and $8.20 \mathrm{Bqkg}^{-1}$, respectively for all around Hatay. The average activity of eU-238 was measured for Arsuz to $8.5 \mathrm{Bqkg}^{-1}$ as minimum; for 
Samandag county $41.2 \mathrm{Bqkg}^{-1}$ as maximum. The maximum peak is recorded of Samandag to 108.4 $\mathrm{Bqkg}^{-1}$. The average activity of eTh was measured for Erzin to $2.75 \mathrm{Bqkg}^{-1}$ as min.; for Reyhanli county to $36.2 \mathrm{Bqkg}^{-1}$ as max. The max. peak is recorded of Reyhanl1 to $38.1 \mathrm{Bqkg}^{-1}$. The average activity of ${ }^{40} \mathrm{~K}$ was measured for Erzin to $63.6 \mathrm{Bqkg}^{-1}$ as min.; for Reyhanli county to $420.4 \mathrm{Bqkg}^{-1}$ as max. The max. peak was recorded of Kirıkhan to $659.2 \mathrm{Bqkg}^{-1}$. The average activity of ${ }^{137} \mathrm{Cs}$ was measured for Belen to $1.8 \mathrm{Bqkg}^{-1}$ as min.; for Hassa county to $19.1 \mathrm{Bqkg}^{-1}$ as max. The max. peak is recorded of Hassa to 39.8 $\mathrm{Bqkg}^{-1}$. Average values regarding the counties of Hatay were given in Table 1. Comparison will be possible with the other cities for Hatay province in Table 2. Besides, activity map of eUranium was given only as an example in Fig. 2, too. Besides, terrestrial gamma dose rate map was also shown in Fig. 3. Now, it is possible to calculate ADRA and AEDE values [1] by using these concentrations in Eqs. (1) and (2):

$$
\begin{gathered}
A D R A=0.461 * A_{U}+0.623 * A_{T h}+ \\
0.0417^{*} A_{K}+0.1243^{*} A_{C s} \\
A E D E=A D R A^{*} D C F^{*} O F^{*} T
\end{gathered}
$$

Where ADRA is absorbed dose rate in air $\left(\mathrm{nGyh}^{-1}\right)$, $\mathrm{A}$ is activity, DCF is dose conversion factor $(0.7 \mathrm{~Sv}$ $\left.\mathrm{Gy}^{-1}\right)$, OF is outdoor occupancy factor $(0.2), \mathrm{T}$ is exposure time $\left(8,760 \mathrm{~h} \mathrm{y}^{-1}\right)$. AEDE is annual effective dose equivalent $(\mu \mathrm{Sv})$. By using data from Table 1, now it is possible to assess ADRA and AEDE values by means of Eqs. (1) and (2). ADRA and AEDE

\begin{tabular}{|c|c|c|c|c|c|}
\hline $\mathrm{Nm}$. & County & ${ }^{226} \mathrm{Ra}(\mathrm{eU}-238)$ & ${ }^{208} \mathrm{Tl}$ (eTh-232) & ${ }^{40} \mathrm{~K}$ & ${ }^{137} \mathrm{Cs}$ \\
\hline S & Name & $\mathrm{Bqkg}^{-1}$ & $\mathrm{Bqkg}^{-1}$ & $\mathrm{Bqkg}^{-1}$ & $\mathrm{Bqkg}^{-1}$ \\
\hline (5) & Altınözü & $22.6 \pm 1.4$ & $7.52 \pm 0.6$ & $172.8 \pm 14.9$ & $2.0 \pm 0.3$ \\
\hline (10) & Antakya & $22.4 \pm 1.4$ & $13.6 \pm 0.9$ & $202.6 \pm 17.8$ & $8.4 \pm 0.7$ \\
\hline (2) & Arsuz & $8.5 \pm 0.6$ & $8.8 \pm 0.5$ & $209.5 \pm 16.3$ & $3.6 \pm 0.3$ \\
\hline (2) & Belen & $11.7 \pm 0.8$ & $11.6 \pm 0.8$ & $179.5 \pm 14.6$ & $1.8 \pm 0.3$ \\
\hline (2) & Dörtyol & $20.4 \pm 1.2$ & $20.2 \pm 1.3$ & $322.8 \pm 25.6$ & $2.1 \pm 0.2$ \\
\hline (2) & Erzin & $13.3 \pm 0.8$ & $2.75 \pm 0.3$ & $63.6 \pm 6.2$ & $16.0 \pm 1.2$ \\
\hline (9) & Hassa & $23.7 \pm 1.4$ & $19.5 \pm 1.2$ & $338.4 \pm 26.8$ & $19.1 \pm 1.3$ \\
\hline (5) & Iskenderun & $16.9 \pm 1.1$ & $9.8 \pm 0.8$ & $192.2 \pm 17.8$ & $3.0 \pm 0.4$ \\
\hline (4) & Kırıkhan & $13.8 \pm 0.9$ & $14.9 \pm 1.0$ & $274.9 \pm 22.0$ & $2.4 \pm 0.3$ \\
\hline (2) & Kumlu & $16.9 \pm 1.3$ & $15.7 \pm 1.3$ & $250.0 \pm 23.4$ & $6.3 \pm 0.8$ \\
\hline (3) & Reyhanlı & $38.9 \pm 2.2$ & $36.2 \pm 3.3$ & $420.4 \pm 33.7$ & $18.8 \pm 1.5$ \\
\hline (6) & Samandag & $41.2 \pm 2.3$ & $11.6 \pm 0.9$ & $173.1 \pm 16.0$ & $5.6 \pm 0.5$ \\
\hline (3) & Yayladag & $26.6 \pm 1.6$ & $15.1 \pm 0.9$ & $327.8 \pm 26.2$ & $3.4 \pm 0.4$ \\
\hline$(55)$ & Average & $23.35 \pm 1.40$ & $14.55 \pm 0.97$ & $242.36 \pm 20.12$ & $8.20 \pm 0.68$ \\
\hline
\end{tabular}
values are given in Table 3.

Table 1 Activity concentrations of eUranium, eThorium, Potasium and Cesium.

Table 2 Comparison of the activity concentrations for a few Turkish provinces.

\begin{tabular}{lllll}
\hline Country & ${ }^{226} \mathrm{Ra}(\mathrm{eU}-238)$ & ${ }^{208} \mathrm{Tl}(\mathrm{eTh}-232)$ & ${ }^{40} \mathrm{~K}$ & ${ }^{137} \mathrm{Cs}$ \\
\hline Name [ref nm.] & $\mathrm{Bqkg}^{-1}$ & $\mathrm{Bqkg}^{-1}$ & $\mathrm{Bqkg}^{-1}$ & $\mathrm{Bqkg}^{-1}$ \\
\hline Hatay [10] & 23.35 & 14.55 & 242.36 & 8.20 \\
Adana [4] & 17.6 & 21.2 & 297.50 & -- \\
Çanakkale [5] & 94.55 & 110.40 & $1,273.00$ & 19.39 \\
Gaziantep [8] & 25.20 & 23.70 & 289.20 & 8.02 \\
İstanbul [7] & 21.00 & 37.00 & 342.00 & -- \\
Kirklareli [9] & 37.00 & 40.00 & 667.00 & 8.00 \\
Şanliurfa [3] & 20.80 & 24.95 & 298.60 & 9.08 \\
Tekirdağ [6] & 29.00 & 39.00 & 580.00 & 5.20 \\
World [1] & 33.00 & 45.00 & 420.00 & -- \\
\hline
\end{tabular}




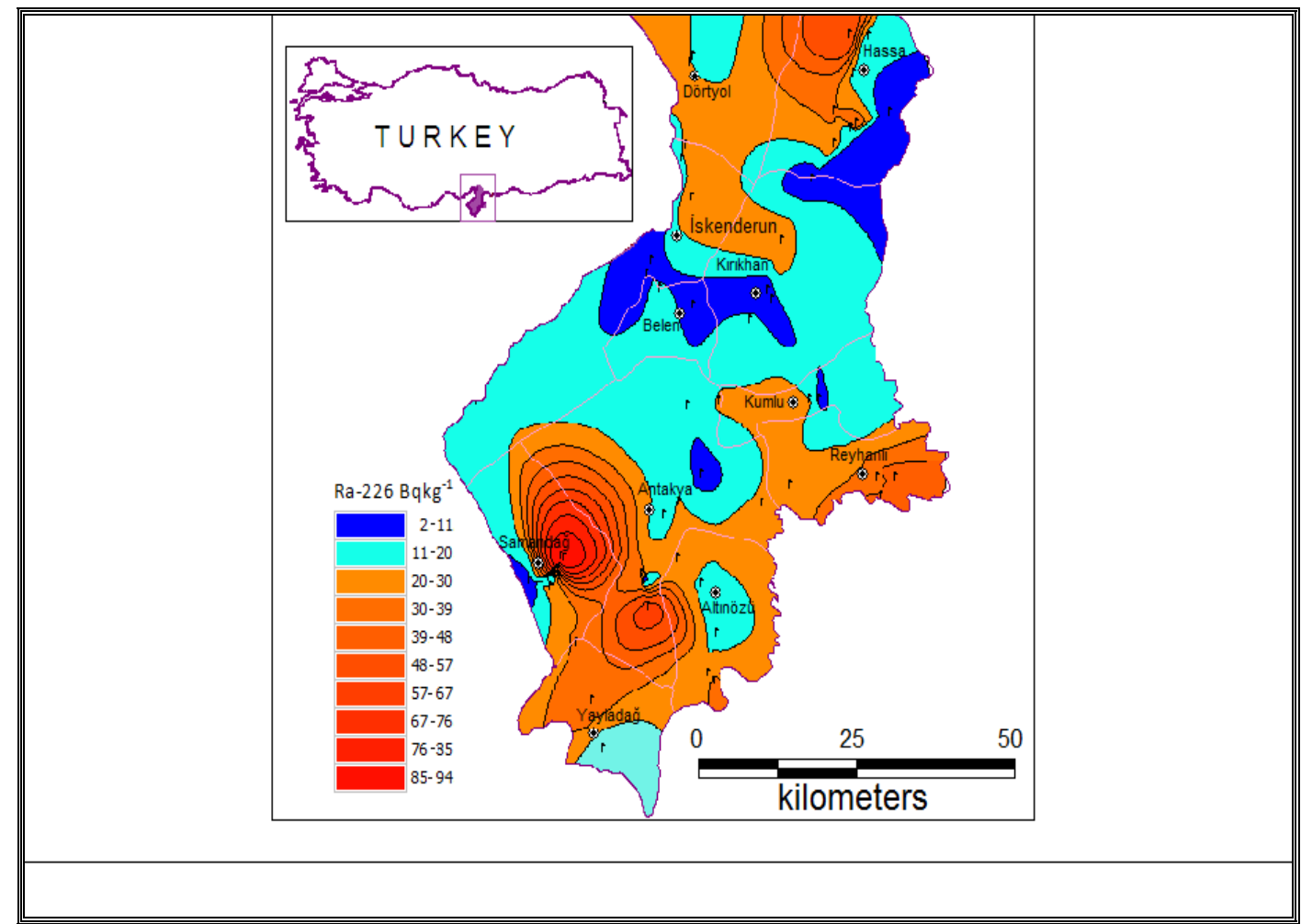

Fig. 2 Activity (eU-238) map [11].

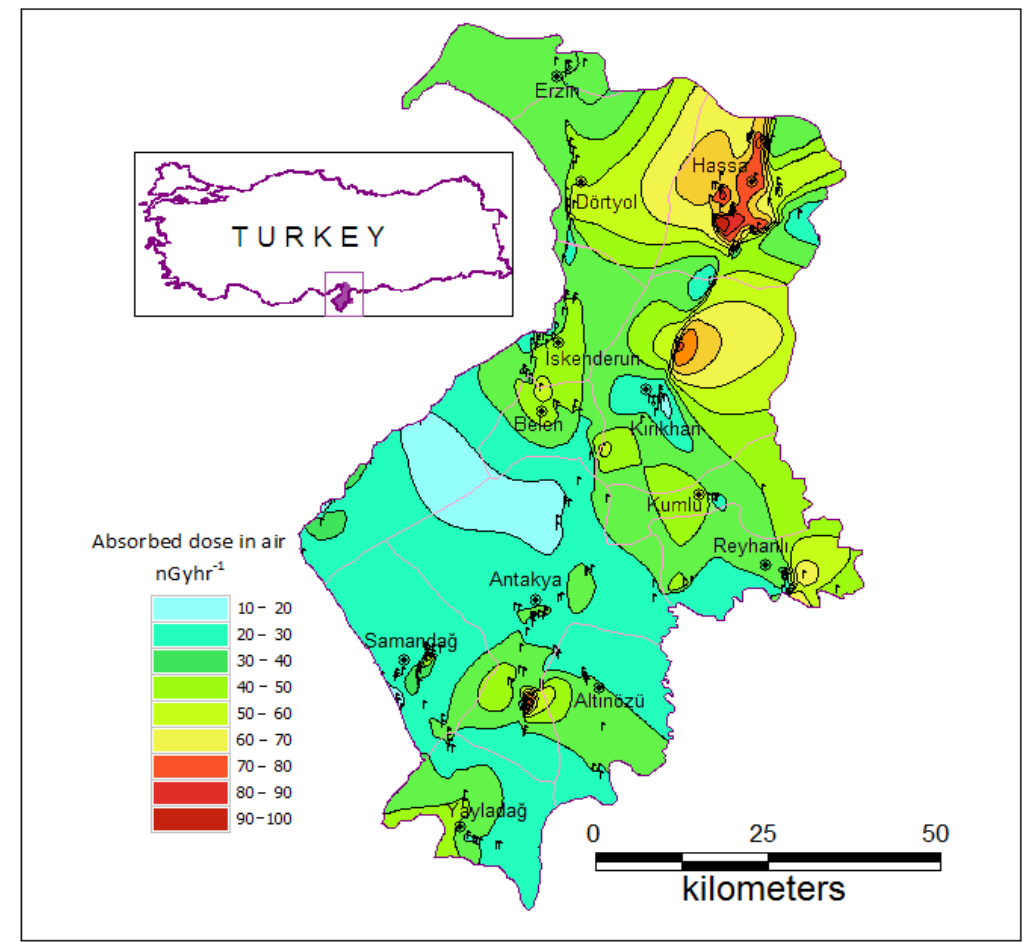

Fig. 3 Terrestrial gamma dose rate in air [11]. 
Table 3 ADRA and AEDE values regarding Terrestrial Gamma Ray effects of Hatay.

\begin{tabular}{llllll}
\hline County & ADRA $\left(\mathrm{nGyhr}^{-1}\right)$ & AEDE $(\mu \mathrm{Sv})$ & County & ADRA $\left(\mathrm{nGyhr}^{-1}\right)$ & AEDE $(\mu \operatorname{Sv})$ \\
\hline Altı̈özü & 22.56 & 27.67 & Iskenderun & 22.28 & 27.33 \\
Antakya & 28.29 & 34.70 & Kirıkhan & 27.41 & 33.61 \\
Arsuz & 18.58 & 22.79 & Kumlu & 28.78 & 35.30 \\
Belen & 20.33 & 24.93 & Reyhanl & 60.35 & 74.02 \\
Dörtyol & 35.71 & 43.80 & Samandag & 34.13 & 41.86 \\
Erzin & 12.49 & 15.31 & Yayladag & 35.76 & 43.86 \\
Hassa & 39.56 & 48.52 & HATAY & 30.95 & 37.96 \\
\hline
\end{tabular}

\section{Conclusion}

It is seen that in the Comparison table, average values in the world were seen for Uranium, Thorium and Potasium as 33, 45 and $420 \mathrm{Bqkg}^{-1}$ respectively. For just a few points, activities are up the limit values, which could be reasoned due to changes for concentrations of primordial nuclides and also altitudes. Nearby, Hatay average results are under these limits. ADRA is $30.95 \mathrm{nGyh}^{-1}$ and Annual Terrestrial Gamma dose originates of these nuclides effect, is calculated to $37.96 \mu \mathrm{Sv}$. Old studies were shown that the average of limit value, for terrestrial gamma dose rate (ADRA) is $60 \mathrm{nGyh}^{-1}$ [1]. The world average annual terrestrial gamma dose (AEDE) was declared to $70 \mu \mathrm{Sv}$ in literature [1]. These results, in our study, indicate that: there is no risk which originates to the soil samples around Hatay region. It could be said that there is no risk to human healthy, comes from the Uranium, Thorium, Potasium and Cesium stated inside of soil around Hatay province in Turkey. Besides, the data obtained in this study are baseline for future studies which can be used to evaluate possible changes. For example, after a possible nuclear attack, it would be performed the comparison with early values, too.

\section{Acknowledgments}

Author will give many thanks to Halim Taşkın and F. R. Küçükcezzar, a physician at CNAEM/TAEK. This study was supported by BAP/GAUN [MF.14.01].

\section{References}

[1] UNSCEAR. 2000. Sources and Effects of Ionizing Radiation. Report of the United Nations Scientific Committee on the Effects of Atomic Radiation to the General Assembly, United Nations, New York.

[2] Hatay Province in Turkey/Google Earth.

[3] Bozkurt, A., Yorulmaz, N., Kam, E., Karahan, G., and Osmanlioglu, A. E. 2007. “Assessment of Environmental Radioactivity for Sanliurfa Region of Southeastern Turkey." Radiation Measurement 42: 1387-91.

[4] Değerlier, M., and Karahan, G. 2007. "Annual Effective Dose of Natural Environmental Radioactivity Measurements for Adana Region.” Ph.D. thesis, NSI-CU/Adana.

[5] Kam, E., Bozkurt, A., and Ilgar, R. 2010. "A Study of Background Radioactivity Level for Canakkale, Turkey." Environ. Monit. Assess. 168: 685-90.

[6] Kam, E., Yarar, Y., and Bozkurt, A. 2010. "A Study of Background Radioactivity Level for Tekirdag, Turkey." Radiat. Prot. Dosim. 138 (1): 40-4.

[7] Karahan, G. 1997. "Natural Environmental Radioactivity Measurement in Istanbul.” Ph.D. thesis, EE-ITU/Istanbul.

[8] Osmanlioglu, A. E., Kam, E., and Bozkurt, A. 2007. "Assessment of Background Radioactivity Level for Gaziantep Region of Southeastern Turkey." Radiat. Prot. Dosim. 1244: 407-10.

[9] Taskin, H., Karavus, M., Ay, P., Topuzoglu, A., Hidiroglu, S., and Karahan, G. 2009. "Radionuclide Concentration in Soil and Lifetime Cancer Risk due to Gamma Radioactivity in Kirklareli, Turkey.” Journal of Environmental Radioactivity 100: 49-53.

[10] Turgay, M. E. 2015. "Assessment of the Environmental Radioactivity in Hatay Region." Ph.D. thesis, NSI-GAUN/G. Antep.

[11] Software for Charts, CNAEM/TAEK.

[12] http://www.canberra.com/products/detectors/germaniumdetectors.asp. 